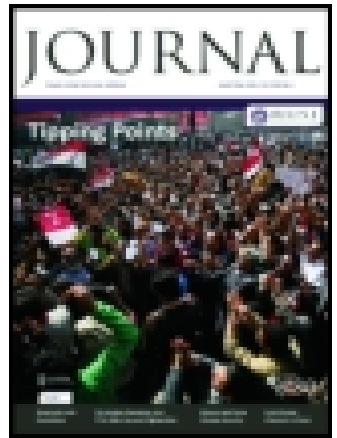

Royal United Services Institution. Journal

\title{
Two Memoranda Regarding the Defences Harbours, and Railways Required by China
}

\section{Lieut.-Colonel Rheinhold Wagner \& Captain P. Holland}

To cite this article: Lieut.-Colonel Rheinhold Wagner \& Captain P. Holland (1898) Two Memoranda Regarding the Defences Harbours, and Railways Required by China, Royal United Services Institution. Journal, 42:246, 941-966, DOI: 10.1080/03071849809417397

To link to this article: http://dx.doi.org/10.1080/03071849809417397

曲 Published online: 11 Sep 2009.

Submit your article to this journal ¿

Џll Article views: 5

Q View related articles 5 


\title{
TWO MEMORANDA REGARDING \\ THE DEFENCES, HARBOURS, AND RAILIVAYS REQUIRED BY CHINA. ${ }^{1}$
}

\author{
By Liett.-Colonel RHEINHOLD WAGNER.
}

'Translated by permission by Captain P. Holland, 5th Punjab Infantry.

Supplement No. 6 of 1 S0S to the Militär-Wochenblatt.

\section{Contents.}

I. Memorandum on the most imporfanl railicuy's and defonsive zcorks.

1. Introductory remarks.

2. Fortifications, railways, etc. (required for the protection of Peking), in the province of Chi-li.

3. Defensive works and railways required for the Northern fleet, and for the protection of the approaches to Peking from the South.

4. Main lines and defensive works generally.

5. Conclusion.

II. Nemorandum on harbours, connecting railways, etc., required by the Northern Chinese fleet.

1. Introduction.

2. Port Arthur.

3. Wei-hai-Wei.

4. Kiao-Chou Bay'.

Concluding remarks.

\section{Prefatory Remarks.}

AT the beginning of November, 1881, I was brought into communication with the Chinese ambassador in Berlin, Li Fong Pao. After discussing various other questions relating to the French proceedings in Tongking, the ambassador showed me, in June; 1883, a map of Port Arthur, the proposed depott.for the Northern Chinese fleet (the Pejang squadron), and asked me for proposals as regards its fortification. These I drew

'Many of the names mentioned in this paper are not marked on the English map consulted during translation.-P. H. 
up on general lines, stating at the same time, that though the position was undoubtedly one of great strategical importance, it was not sufficiently well adapted for the requirements of a naval base for a large flect, being suitable only for a small depôt, or second-class harbour. I pointed out that some other spot must be selected as the main naval base. The ambassador thereupon sent me the English Admiralty maps, with a request that I would give my opinion as regards the suitability of Society Bay, and Port Adams, north of the Liao-tang Peninsula, and also as regards Ta-lien-wan. He also attached a naval chart of Port Arthur with the remark that perhaps on perusal of the same I might be clisposed to modify my previous remarks. I held to my first opinion, however, and still maintained that the object in view was to be sought for elsewhere than in any of the places mentioned.

Richthoven's book on China was then unknow'n to me, but a study of the smaller maps drew my attention to the excellent strategical position of Kiao-Chou Bay. It was not, however, till November that the ambassador sent me the English Admiralty map of this locality, together with one of Wei-hai-TVei, asking my opinion as to the suitability of both for naval purposes. To this I replied that like Port Arthur, Wei-hai-Wei, though of strategical importance was, owing to its conformation, unsuited as a large naval base, but, that in $\mathrm{my}$ opinion, Kiao-Chou Bay was eminently adapted as such. I sent him at the same time a short sketch of my proposals as regards improvements and fortifications, etc.

Meanwhile affairs in Tongking had reached an acute stage. The French held the Chinese Government directly responsible for the continued resistance of the Tonkinese, and in December, 1883, it was announced in the Senate that Chinese territory would have to be taken until the Chinese Government redeemed the cost of the military operations in Tongking.

In February, 1884, when the French were expected to occupy BacNinh, I explained to Li Fong Pao that Clina must now either come to some satisfactory understanding with France regarding Tongking, or find herself engaged in another war, which would result in operations against Peking itself, as the French would realise that it was there only that they could definitely settle the matter. War I could certainly not counsel, as China was in no sense prepared for a big campaign, and it would require at least ten to fifteen years in which to complete her military and naval preparations, railways and fortifications, etc. Meanwhile, the firench could be left to their own devices in Tongking. They were bad colonists, and could easily be expelled, if China only seized the right moment.

A European conflagration would be the most opportune time, and the more complete the preparations made by China, the more numerous would be her allies. On the ambassador's expressing a doubt whether an agreement with France, more especially as regards her disclaimer of indemnification, could be arrived at, I replied that the proposed conditions of the agreement appeared to me to be favourable to 
both parties. We then discussed military and other measures necessary. When I mentioned the great importance of railways in war-time, the ambassador was-much struck. The Central Government had prevented the construction by foreigners (with permission of the provincial governor) of the small railway from Wusung to Shanghai. The stringent law against the construction of any railways in China was still in force, and it would be scarcely possible to cancel the same merely in the interests of commerce; but I thought it might not be impossible if the vast importance of railways in connection with the defence of the country were clearly demonstrated. I therefore seized the opportunity, when discussing the defences of Peking and its approaches, of clemonstrating on the map the immense value, even within the limited area of Chi-li, of a small railway system, pointing out the possibility of a hostile landing, not only, as in 1860, at the mouth of the Pei-ho, but also at Ninghai and Shan-haikwan. These observations seemed to impress the ambassador greatly.

Coast batteries at Shan-hai-kwan, and other fortifications at Tạku, Tientsin, and Peking could now be carried out provisionally, while permanent works, harbours, and railways must be constructed on some definite and well-considered general scheme, which I now undertook to draw up.

While I was thus occupied, the papers reported the construction of batteries at Shan-hai-kwan (Ninghai), and subsequently, in April, it was stated that Li-Hung-Chang had memorialised the Empress-Regent regarding the peace with Erance, the preliminary treaty of Tientsin being concluded in the following May. ${ }^{1}$ About the middle of June, Li Fong Pao came to me with a map of China, asking that I would show thereon the proposed railways. This I did as well as possible on the spot, but the ambassador gave me no clue as to his sudden request. Ten days later, however, the Times published a telegram from Peking to the effect that the restriction as regards railways was cancelled, and that the Tsung-li-Yamen had asked the diguitaries to consider the question favourably. Li Fong Pao had therefore presumably been also instructed to this effect.

By the encl of July, 1884, I had completed my scheme dealing with coast defences from Tongking to Corea, and the most important land defences. All Jocalities adapted for naval purposes were included; the naval headquarters of the Southern fleet being fixed in the Samsah Bay, and that of the Northern fleet in Kiao-Chou Bay, and finally I drew up a complete though general scheme for harbour improvements and defences at these places. (See PI. 8.)

Besides harbours, the scheme dealt with the fortification of Canton, the mouths of the Canton river in the South, the Taku and Petang in

1 France waived her claim to indemnification onaccount of the war in Tongking, and undertook, by the treaty of peace, to leave the nominal suzerainty of Annan and Tongking in the hands of the Emperor of China, in return for which China bound herself not to disturb the French in Tongking, and open up the provinces bordering on Tongking, viz., Yunnan, Kuangsi, and Kuantung, to trade. 
Chi-li, and the defences of Tientsin and Peking in the North, giving general proposals for the same.

After being translated into Chinese, the work (consisting of two folio volumes with 55 maps and plans) was sent in the autumn of 1884 to China, but what further was done in the matter I cannot say, Li Fong Pao having been recalled. It is however, certain that my proposals reached the hands of certain German officers, who were employed in China in the autumn of 1884 , when it was anticipated that war would break out with France owing to the violation of the preliminary treaty of Tientsin, and the bombardment of Fuchen-fu, and that one of these officers, an engineer, visited Kiao-Chou, and expressed a most favourable opinion as regards its value for defensive purposes. Nothing further was, however, done. Only recently the China Gazelle has stated that Li-HungChang reported to the Throne, in 1892 , that Kiao-Chou was admirably adapted as a naval base. At the same time he requested permission to commence the construction of fortifications and a railway to the coal mines in the vicinity. This request was granted, and General Tschang (who has now handed over to the German authorities) was nominated commandant of Kiao-Chou, with orders to construct batteries. ${ }^{1}$ In 1894 Li-Hung-Chang himself inspected Kiao-Chou, and ordered the construction of a dock, which was, however, stopped, owing to the Japanese war. The matter is said to have then dropped until Russian designs to obtain Kiao-Chou Bay again aroused the Chinese Government. Several mandarins were sent there, and after a long consultation, in September, 1897 , the construction of new defences in place of the old batteries was decided upon for the spring of 1898 .

All this has, as I have stated, only recently come to light. Meanwhile, since 1885, things had taken a different turn for me, $\mathrm{Li}$ Fong Pao's degradation having apparently been accompanied by the disappearance of my scheme.

Consequent on the repeal of the law against railways, various Europcan banks and commercial firms applied for railway concessions. At the request of one of these companies; I had, in 1885, drawn up a big railway scheme for the whole of China, including 34 maps and plans. I explained to the representatives, during the first conference, on 10 th December, that the greatest difficulties presented themsclves as regards railway construction, but that the construction of defensive works and harbours would be far more favourable. I pointed out the innate dislike of the Chinesc to railways, their superstition, etc., whereas fortification was an idea with which they were familiar from time immemorial, and that they were keenly interested in the construction of naval bases. I specially demonstrated the immense importance of coming to some agreement with Government regarding land at Kiao-Chou, so as to eventually acquire a German naval base.

This appeared to me of such importance that I wrote a letter on the subject two days later. As the delegate of the firm would probably

\footnotetext{
${ }^{1}$ Found on the landing of the Germans.
} 
DEFENCES, HARHOURS, AND RAILIVAYS REQUIRED BY CHINA. 945

reach Shanghai in the winter, and could not reach Tientsin before the Pei-ho was free of ice, I recommended their obtaining the support of the German Government, an examination being meanwhile made of KiaoChou Bay, by a German vessel from the Fast Asiatic station, with the delegate on board, and that I should be put in communication with the Admiralty directly this was to be carried out. No reply was, however, received.

On the 18th December, when visited by a leading member of the firm, I repeated my proposal most forcibly, but without any result, and my connection with the railway question was therefore very limited. I attached my memorandum on Kiao-Chou Bay and the defence of Taku and Petang, Tientsin, and Peking, to the other papers which had been given to the delegates, in order that they might be in a position to consider the matter should they find railway concessions impracticable, and the company had decided to submit my memorandum, and plans, to the German ambassador (von Brandt) in Peking, but this was never done.

The efforts of the delegates during 1886 having proved the correctness of my views, I made a fresh attempt to direct their attention to my proposals, and accordingly published, at the beginning of December, 1886, these two memoranda for translation into Chinese and communication to the persons concerned in Tientsin and Peking.

These memoranda are, therefore, to a certain extent, an extract from the larger ones of 1884 and 1885 , more especially as they deal with Tientsin and Peking, and the northern portion of China. For this reason also they are of special interest to us.

The dissolution of the company, however, rendered the work impossible.

I need only remark that Kiao-Chou Bay left me no peace, and least of all when Colonel Liebert was about to undertake a mission to Peking, in November, 1896, and frequently applied to me for information. His unprecedented nomination as governor of IVest Africa was, therefore, a fresh disappointment, but it is to be hoped the last in this direction.

\section{MEMORANDUM I.}

Railways and Fortifications in China.

\section{1.-Introduction.}

When, during the Tongking development, the Chinese Government were busily engaged in preparing to meet a French attack, China's friends in Germany expected that a stout resistance would be offered to the French. When experience, however, proved that neither army, navy, defences, nor railways were available to cope with a war, or could be supplied within reasonable time, the actual outbreak of hostilities was viewed with no little anxiety. In short, it was known that should the French decide on a campaign, the capital itself was in danger. 
It must, therefore, be regarded as fortunate for China that peace was concluded before the French put forth their whole strength, and decided to attack Peking.

Time was gained, and it was hoped that the opportunity would be seized to supply all the requirements for a successful defence of the Empire. These expectations have, however, strange to say, never been realised. Since the time when the Chinese Government were said to have contemplated building railways two and a half years have already passed without anything in this shape having been commenced, and moreover the capital still remains defenceless.

With the momentary disappearance of danger there appears to be no emergent need for preparation, and it does not seem to be realised by the Chinese in how short a time matters may develop, or how long it would take to complete the fortifications and railways required for the defence of such a vast country. The most important of these, at least, should be commenced without delay, and I will now show what these are:-

\section{2.-Fortifications and Raimivar in Chi-li Necessary for the} Defence of Peking.

A glance at the map, as also a study of history, shows us that Peking can be casiest attacked from the sea, and it is therefore especially important that an adequate flect and defences should exist in this locality. The length of the coast-line is however so great that it would be practically impossible to prevent an enemy landing at some point. On the other hand, there is no great danger in certain isolated spots only being occupied, and the. enemy having even penetrated into the interior. China would certainly never be compelled to conclude a disadvantageous pence by this means, whereas with Peking at the mercy of the invader he could dictate what terms he liked.

This is the residence and headquarters of the Royal Family and Government, whence all orders are issued to the various viceroys and provincial governors. With Peking in danger and the Emperor compelled to abandon the tombs of his ancestors, the whole army and nation would be convulsed, and anarchy and dismay would reign supreme throughout the length of the land.

Every possible means must be taken to preclude such a possibility, rendered as it is even greater by the geographical position of Peking. On the other hand, nature has provided the means of the danger being overcome, if only the requisite measures are taken.

Winter in the province of Chi-li being so severe that the ice on the rivers and on the roads is never melted till about the middle of March, no hostile army could attempt the feat before the end of that month, and in the middle of November the frost sets in again. If therefore an enemy had failed to reach Peking in the interim, he would be driven back to his ships. If he desired to winter on land he would be cut off from all communication with the flect, and could not receive his supplies or ammunition. An army would soon suffer from want and sickness, and 
if attacked by overwhelining masses of Chinese troops would have no means of escape. In any case, the campaign would be a failure unless Peking were occupied before winter had set in. If Peking could have been defended only for a few weeks in 1860, the French and English would have had to retire without attaining their object.

The measures adopted for the defence of Peking must be, therefore, so directed as to keep an enemy in check during the summer, and primarily, therefore, the city itself must be strongly fortified, and this compared with other proposals for its protection is by far the simplest, cheapest, and most effective. This is, however, of course not all that is required. An enemy must be prevented from getting as far as Peking, and the approaches to that city must therefore be defended, including the most important points along the same, and places on the coast near which bodies of the enemy might land. The ancient forts themselves demonstrate that their constructor appreciated the necessity of completely protecting this city centuries ago; but the events of 1860 showed that the existing works were altogether insufficient when attacked by a modern arm, and more especially by modern guns. The old circular wall is too narrow on the top to take guns and protect them with breastworks. The existing earthworks give no protection, and if shelled the splinters would prove most dangerous to the garrison. The whole wall can be seen and shelled from a great distance, and that too without heavy ordnance. Once these walls were breached, the assault would be an easy matter. 'The old wall must therefore be entirely replaced.

Further, to adequately protect the interior buildings (palace, etc.) from bombardment, a circle of forts should be erected at such distance from the city as to prevent the enemy getting their artillery within range of it. These would have to be not less than 20 li (10 to 11 kilometres) distant from the palace, and not more than 7 to $8 \mathrm{li}$ ( $3 \frac{1}{2}$ to 4 kilometres) distant from one another. Their exact position would, however, be determined by the configuration of the ground. To the west, for instance, they would have to be pushed forward to the hills, $30 \mathrm{li}$ (15 to 16 kilometres) distant from the city, as they could not be constructed in the plain under the hills. Steps should also be taken to prevent the Imperial Palace and Gardens of Wanshoo-Shan, Yu-Chuan-Shan, and Hsiang-Shan, as also the Camp of Tsang-lung-Chiao and the Temple of Bada-Chou falling into the enemy's hands.

Had a strong circle of forts existed in 1860, the English and French would never have been able to destroy the Summer Palace at Yuen-heinYuen.

By an extension of such a circle, the further immense advantage would be gained that Peking could not be invested by the enemy, since they could not concentrate a sufficient force before the city. The Emperor and officials could thus remain in communication with the provinces, as in peace-time, even supposing that a hostile army were operating on one side of the city.

If Peking were, therefore, defended as suggested, it could never be captured, for it could be neither assaulted, bombarded, invested, nor 
starved out, and moreover a regular siege or investment would be out of the question, as there would not be enough time for an enemy to land, defeat the Chinese army, and then bring up heavy siege trains and commence operations before the commencement of winter. The Emperor and the Government could thus remain undisturbed in the capital.

The defence of Peking is thus the main point in the protection of the Empire and the Imperial dynasty.

All other measures of sccurity are of less importance, but, as already stated, the enemy must be held in check as far as possible on the lines of approach, which are as follows:-

1. From the mouth of the Pei-ho, and Petang-ho through Tientsin and Tung-Chou.

2. From Manchuria (Mukden) through Shan-hai-kwan and TungChou.

3. From Mongolia, through Si-feng-kou, Ku-pei-kou, and Nankow.

4. From the south, the roads from Tsi-nan-fu and Kai-feng-fu.

The greatest danger is to be apprehended from the coast, more especially in the vicinity of Taku, Petang, and Shan-hai-kwan, where an enemy might land with a view to an advance on the two first-named roads; of these, the more important is that running along the Pei-ho, being the shortest route to Peking, and because the mouths of the Pei-ho and Petangho would permit of communication being retained between the fleet and the ariny, and because the Pei-ho would form an excellent waterway for the transport of supplies, ammunition, etc., and could even be utilised for bringing up the heaviest siege guns.

Fortifications already exist at Taku and Petang, but it is very doubtful if any of them fulfil modern requirements, being formed out of obsolete earthworks, and having been constructed in a great hurry. It is more especially necessary to fortify the land side so that they could not be taken in rear (as in 1860). The garrison would have to hold out until reinforcements arrived from the interior. The defences of Taku and Petang must be therefore improved on some well-defined scheme.

Besides this, Tientsin must be fortified. The old walls which encircle the inner city and the earthwork built by San-ko-li-tsin in 1860 round the suburbs is now valueless, and the detached forts recently built on the side towards the lower Pei-ho are inadequate. The city must be made into a big fortress, with a strong wall all round as a protection against an assault, and a circle of detached works as a security against bombardment, or investment. Thus, not only would the Pei-ho and the roads leading to Peking be blocked, but the large quantities of supplies within the city would be sccure. The Chi-li army would be completely protected within the circle of forts, and yet able to advance between them at any time. The enemy would not dare to leave Tientsin on the flank when advancing to Peking, as his retreat to Taku would thus be cut off. He would be therefore obliged to take Tientsin first, and this operation would occupy 
so much time and take so many troops, that a sicge of Peking could not be commenced the same year. Only in the case of Peking being unfortified could he advance direct, with a view to defending himself there, and forcing the Emperor to make terms.

To utilise the second main-road leading to Peking, the enemy would be obliged to land near Shan-hai-kwan, where there are already some coast batteries. Whether they are effective remains to be seen, all that is known being that they were rapidly constructed when war with France was. threatening. It is worthy of special note also that a landing could be: effected not only at Ling-hai between Shoal Point and Creek Point, but also to the south-rest in Shallow Bay, and at Litt-cha-Shwang, and that therefore the whole of this portion of the coast would have to be well fortified, and the roads from thence to Peking effectively blocked. For the latter purpose it would be most advisable to fortify the defile to the west of Funing-Shien, or perhaps Yung-ping-fu could be made into a fortress with detached forts, thus making an entrenched camp here like the one at Tientsin. To secure the road from Mongolia, it would be sufficient to have a few detached forts, as a second road from Shan-hai-kwan meets the one from Si-feng-kou at San-tun-ying, and both could be simultaneously blocked by a fort to the west of San-tun-ying, between that place and m...n-hua-chou.

As regards the roads from Ku-pei-kou and Nankow, forts could be constructed at the most suitable points in the hills.

There is less danger from the roads leading to Peking from the south, although that an attack from this direction is possible was proved by the Tai-ping rebels in $18 \overline{4} 4$, when they advanced to the neighbourhood of Tientsin; and it might occur again if, for instance, an enemy had occupied the Shantung Peninsula.

If Tientsin were well fortified on this side also, it would still further add to the security of Peking. Besides this, there are the streams running from the hills to Tientsin near Pao-ting-fu, which would form a line of defence, the points where the roads cross them being strongly fortified, viz., those from Tsinan-fu and Kai-feng-fu.

Yet with all these proposed fortifications, etc., a defence of the province of Chi-li would be difficult without railways, even supposing that an attack was anticipated from the coast alone. But if; as is possible, France and Russia made a combined attack, the Russians might advance from the land side, and then the problem would be even more difficult.

Assuming that an advance was being made only from the coast, it would remain doubtful until the last moment as to the exact spot chosen. The enemy might for example concentrate near the island of Sha-lei-tien and feign preparation for an attack on Taku and Petang. Then under cover of darkness their fleet might steam away and appear at day-break before Shan-hai-kwan. Or perhaps the fleet might anchor at the mouth of the Luan-ho, land troops, draw off the Chinese forces from Petang and Shan-hai-kwan, and then make the real attack at one of these two points. Two strong forces would have to be permanently at these two points, since it would be impossible to follow a hostile flect from point to point, 
or bring reinforcements up to any required point rapidly enough, without the assistance of railways. Without these, the Taku and Petang and Shanhai-kwan armies could never render mutual assistance nor be adequately reinforced from the interior, more especially from Peking and Tientsin.

There are thus three lines required viz. :-

1. From Peking viâ Tung-chou and Tientsin to Taku and Petang (since constructed to Taku).

2. From Tientsin viä Kaiping to Shan-hai-kwan (a railway has now been built to Kaiping and Shan-hai-kwan, unfortunately not from Tientsin, but from Petang.

3. From Tung-chou to Kaiping.

With these railways and telegraph lines, it would be sufficient to garrison the fortifications at Petang and Taku, and near Shan-hai-kwan, merely keeping small bodies for immediate defence of the coast, while the main army of Chi-li was retained in Tientsin and the Imperial troops in Peking, until it was absolutely certain where the enemy would really effect a landing. For since the landing preparations for disembarkation would occupy several hours after anchoring, and the coast batteries must first be silenced, troops could easily be brought up from Tientsin and Peking in time to prevent a landing, or fall upon the first troops landed with overwhelming numbers.

Taku and Petang could be reached from Tientsin in 2 hours at the outside, by rail, even with heavy military trains. From Peking to these points would take 5 or 6 hours; from Tientsin wiâ Kaiping to Shan-haikwan, 8 hours; from Peking to Shan-hai-kwan, 10 hours, and this at a speed not exceeding 30 kilometres $(18$ miles) an hour. With smaller trains, any threatened points could be reinforced with even greater rapidity, and in any case with the aid of these 3 lines it would be possible for the whole of the Chi-li troops to be in position to mect any attempt at landing.

At the same time, it should be noted that these lines must be constructed between the above points on certain principles. From Peking to Tung-chou the line should run north of the canal between the two cities, so as to be protected from an enemy advancing from Tientsin. Further, it should be well covered by the defences of Peking and detached forts. At Tung-chou, the line should branch, in one direction to Kaiping, and in the other to Tientsin, following the right bank of the Pei-ho to the latter place, where it would cross the river on the north side of the city, thence leaving the river and running direct to Sin-ho. From thence it should branch to the right to Taku and to the left to Petang.

The line from Tientsin to Shan-hai-kwan should run towards Lutai (or Ning-ho-shien) north of the streams between the Pei-ho and Petangho, and thus being protected against any attack from troops landing in the vicinity of Taku and Petang. After running south of the hills from Kaiping to Luan-chou, the line should traverse the valley of the Luan-ho to Yung-ping-fu and thence through the pass west of Funing-shien to Shan-hai-kwan. It would thus not follow the coast too closely east of 
Luan-chou, and would further be protected by forts at Funing-shien or by fortifying Yung-ping-fu.

Instead of a line from Tientsin direct viâ Lutai (or Ning-ho-shien) to Kaiping, the one from Tientsin to Petang might be extended up the Petang-ho (Tshan-ho) to Lutai (or Ning-ho-shien); but this again would be a mistake, as, once landed near Petang, an enemy could interrupt communication between Tientsin and Shan-hai-kwan, and then might even himself utilise the line from Petang to Kaiping, and thence to Peking. Besides this, on reaching Kaiping, he could obtain coal for his fleet at Petang, and stop the coal supply for Tientsin, and also that for the troops and gun-boats on the Pei-ho, and at Taku.

A railway should therefore be built, not from Kaiping to Petang, but from Kaiping to Tientsin. .

The railways above advocated would protect the province of Chi-li from an attack from the sea, and also facilitate the defence-of Peking against an attack from the northern, or Russian, frontier, enabling the troops on the coast and at Tientsin, to reach Peking in 8 to 10 hours.

The enemy should not, however, be awaited there, but should be attacked as near the fronticr as possible and on the road to Peking, and it would therefore be of the greatest advantage to have a railway from Peking zitî Nankow to Chang-kia-kou (Kalgan).

The construction of forts at suitable points in the hills along this route has already been advocated, and if a railway existed it would suffice to merely keep these forts garrisoned in the ordinary way, pushing small bodics, cavalry more especially, towards the frontier, to watch the enemy and ascertain his movements. It would be unnecessary to maintain a big army permanently on the frontier where it would be extremely difficult to bring up supplies and ammunition, etc.

Whilst the enemy were kept occupied with the forts, troops could be sent up north by rail, the journey from Peking to Chang-kia-kou only occupying from 8 to 10 hours, and the northern army being thus easily supplied with all requirements.

Lastly, there are two lines necessary to protect Peking against an attack from the South: one from Tientsin and one from Peking to Pao-ting-fu. The first-named would be merely an extension of the line from Shan-hai-kwan through Tientsin to the west as far as the hills, and running along the lake and marshes near the Tung-ting-ho. The importance of adequately fortifying and defending the crossings of the river has been already alluded to. Since it will, however, be impossible to anticipate the real point of attack, it will be of the greatest advantage to have a railway behind the river, and thus be able to reinforce any given point as rapidly as possible.

If the main body of the Chi-li army held the entrenched camp formed by the detached forts around Tientsin, troops could be despatched from thence, not only as already shown to Taku and Petang, but also to the west in the direction of Pao-ting-fu. The position of Tientsin is therefore eminently of strategical value for the defence of Chi-li, with the aid of railways. 
The second line required for defence against an attack from the south would generally follow the Imperial road, and would enable reinforcements to be brought from Peking to the right flank of the southern defensive line in six hours.

Looking now, generally, at the railway systems which I have advocrited, we find that Peking is the main centre; that further, a railway would run along the whole of the defensive line towards the south-east, from Shan-hai-kwan, viâ Tientsin, to Pao-ting-fu ; Peking would be connected with both fanks and the centre of this.line, at Tientsin, a point projecting from Tientsin towards the most important points of attack, Petang and Taku, and lastly, the rear would be defended from an attack from the Russian frontier, by the line from Peking to Chang-kia-kou.

\section{3.-Fortifications and Rainwals Required for the Nortfere Fleet and Protection of the SoutherN Appronches to PEKING.}

The foregoing works and railways supply the requirements of the defence of the province of Chi-li and Peking by the army, but they need supplementing in two ways.

In the first place, Peking being most threatened from the sea, the Northern fleet is of great importance; whilst secondly, as Northern China does not produce all the supplies for the population and the army, a defence would be impossible, if the approaches from the south were neglected. Fortifications and railways, without which neither the fleet could exist and operate, nor the approaches to Peking be secured, are thercfore indispensable. The first-named I have dealt with scparately in Memorandum II., where it is proposed to retain Port Arthur and Wei-hai-Wei merely as stations and supply depots for the Northern fleet, the main naval base being in Kiao-Chou Bay, and the coal supply being secured by railway connection with Tsi-nan-fu.' 'This would further assist in the transport of supplies to Peking. In peace-time, since the neglect of the Imperial Canal, these supplies are carried from the mouth of the Yang-tse-kiang, and other harbours further south, by sea to Taku and Tientsin. For three months in the year, however, this route is blocked by the ice on the Pei-ho, and it would therefore be an immense boon, even in ordinary peace-time, if Peking were connected with a harbour free of ice all the year round. This is to be found in the Kiao-Chou Bay, and to connect it with Peking it would only be necessary to supplement the line from Kiao-Chou to Tsi-nan-fu, and Tientsin to Peking, with a third line from Tientsin to Tsi-nan-fu. ${ }^{2}$ This would be of special value in case of war. Should, for example, an enemy declare war at the commencement of spring, the supplies shipped to Peking and Tientsin in the previous autumn would be nearly exhausted, and without a railway they could not be replenished, as the sea route would be lost on the outbreak

${ }^{1}$ Germany has meanwhile obtained a concession for this railway.

"A concession has been requested for this line also. 
DEFENCES, HARBOURS, AND RAILWAYS REQUIRED BY CHINA. 953

of war. On the other hand, if Peking were connected by rail with KiaoChou, no matter at what season war broke out, supplies could be brought from the south in large quantities, even when operations had commenced. Meanwhile it would be impossible to foresee how long the war might last, and supplies for Peking could only be secured under all circumstances by railways from thence to the Yang-tse-kiang, protected from hostile attacks. These are two in number, viz. :-From Tientsin viâ Tsi-nan-fu to Chin-kiang-fu, which can, however, only be utilised as long as the enemy have not taken the fortifications at the mouth of the-Yang-tsekiang. These fortifications would therefore be important, not only for the purpose of keeping the enemy out of the Yang-tse-kiang and thus preventing the north from being separated from the south, but because they would also protect the transport of supplies for the north from Chinkiang-fu. They must be, therefore, carefully examined as to their strength, which is of vital importance. Even so, however, they may not be absolutely impregnable, and their fall means that connection with Peking from the south is interrupted, without a second line much further in the interior. This line must therefore be built as far as possible to the west, along the foot of the mountains bordering the plains. The first portion has already beon made, viz., from Peking to Pao-ting-fu already mentioned, and this should be extended through Kai-feng-fu to Hankow on the Yang-tse-kiang. ${ }^{2}$ The construction of these two lines for the transport of supplies from Peking (to Chin-kiang-fu and to Hankow) is of special importance inasmuch as they are both portions of the main lines required for the general defence of the Empire.

\section{4.-Priscipal Railways, and Defensive IVorks Generally. (Sce Pl. 7.)}

If the above railways and fortifications are carricd out, the Emperor, the Dynasty, and the Government will be rendered secure in Peking. There are, however, other measures necessary, the most important of which are those having for their object the defence of the coast, and provinces bordering on Tongking and Russia.

As already explained, the difficulty of coast-defence lies in the fact that a hostile fleet can move about rapidly from place to place, whereas an army can only move slowly, and would therefore have to be in considerable force at many different points; and the only means of removing the difficulty lies in the construction of railways, by which a large force could be concentrated at any threatened point with the utmost rapidity. A line must therefore be built extending at least from Shan-hai-kwan to Canton, so as to protect the main portion of the Empire from an attack from the sea. Fortunately, a great portion of the railway will exist in the shape of the lines from Shan-hai-kwan to Tientsin, and thence to Chin-kiang-fu, and there will remain, therefore,

${ }^{1}$ A concession was demanded also for this line, but objected to by Germany, who bas not only the monopoly of railways in Shantung, but has received a concession for portion of the line in question, viz., from Tsi-nan-fu to Yi-chou.

2 This is now to be carried out. 
only the portion from Canton to Chin-kiang-fu. The river valleys should be utilised as far as possible, and the line should be built so far inland as to be out of range of artillery from the sea, or to incur the possibility of being attacked by small parties of the enemy who might have landed, and it must be connected by small branch lines with the most important harbours liable to attack. The line should, therefore, run from Chin-kiang-fu through Su-chou-fu to Hang-chou-fu, with a branch to Shanghai and Wusung; from Hang-chou-fu to Ning-po, with a branch to Chinhai, and from Ning-po to Canton with a branch to IVenchou, Fu-chou, Amoy, and Swatou.

I have already pointed out where fortifications are necessary in connection with this line north of the Yang-tse-kiang, as also the fact that the fortification of the mouth of that river is of great importance. To the south the harbour towns must be protected, but above all Canton, the mouth of the Canton river, and its tributaries.

This coast-line cannot, however, be absolutely secure under all circumstances. At some points it runs very near the coast, more especially: on the Yang-tse-kiang, where the enemy could entirely interrupt communication, as soon as he had captured or silenced the forts at the mouth of the river, and brought his ships up. The two wings of the great defensive line would then be disconnected. It is therefore necessary that the line from Tientsin to Canton should run in a curve covering a distance about $1 \frac{1}{2}$ times the distance between these two cities, while it may be of vital importance to bring troops from one wing to the other. For it is easily conceivable that operations might be chiefly confined to the south-west (near Tongking) and in the Chi-li Province (Peking being the objective), and therefore a large body of troops might be required to be concentrated in both places, victory depending entirely upon the ability to bring an overwhelming force into the field at the enemy's real point of attack.

A central line is therefore also required, which should be safe from interruption by being built further inland, and which would further connect Peking with the southern parts of the Empire by the shortest possible route. This could be accomplished by merely extending the PekingHankow line to Canton.

Should the alignment between Kai-feng-fu and Hankow or HangChou and Canton through the hills prove too difficult, a circuitous route might be followed to the west through the river valleys, the first portion through Sin-yang, and the second portion through Kwei-lin.

The latter would run up the Si-Kiang valley and would be met. by the coast railway from Canton to Yun-nau, and a branch line should also run from Si-kiang along the Yu-kiang valley to Nan-ning, close to the Tongking frontier. Troops could thus be brought up rapidly from all parts of China and even from Peking to meet a possible French advance.

Several lines are also required towards the Russian frontier, more especially where the Russians have built or are building their own railways. There is already a line from the Caspian to Askabad and Merv, and Charjui on the Amu-Darya, and this is to be extended without delay 


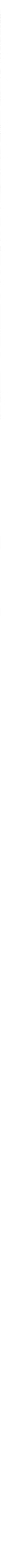


DEFENCES, HARBOURS, AND RAILWAYS REQUIRED BY CHINA. 955

through Bokhara to Tashkent, whence it may be continued round Eastern Turkestan viâ Semirechensk, eventually reaching the Kansu Province and the towns of Urumtsi and Hami.

A second line is also partially opened from Samara through Ufa to Zlatoust, and thence. through Omsk and Semipalatinsk to the Chinese frontier, and this will likewise probably be extended to Kansu, meeting the first-mentioned railway at Hami.

A third branch line is contemplated from Omsk through Krasnoyarsk to Irkutsk and Kiakhta, and thence towards Peking.

Lastly, the Russians will attempt to penetrate Manchuria, the home of the Imperial Dynasty, starting from Irkutsk, passing through their coast province, and eventually reaching Corea.

It is impossible to ignore the fact that Russian railways will soon reach the Chinese frontier. They have only taken a year-and-a-half to build the Trans-Caspian line from Kizl-Arvat to Charjui, and its extension to Tashkent would probably take even less time. It may therefore be assumed that the lines to Semipalatinsk, Irkutsk, and Vladivostock will be completed far more rapidly than was anticipated, and there can be no manner of doubt that these lines are seriously contemplated.

In October (1886) the papers announced that the Governors-General of Siberia and the Amur region had been summoned to St. Petersburg to consider these questions and receive instructions relating thereto. China should, therefore, take immediate action, and construct the following lines :-

1. A western railway through Sian-fu and Lan-chow-fu to Suchow and the Shan-hai-kwan gate of the Great Wall, or better still through Hami to Turfan or Urumtsi. As feeders to this line two railways should be built from the great central (Peking-Canton) line, from Wei-huei-fu and Hankow to Sian-fu.

2. The line from Peking to Chin-kia-kou (Kalgan) should be extended in a north-westerly direction to Urga.

3. The line from Peking (or Tientsin) to Shan-hai-kwan should similarly be extended through Kinchou, Niu-Chuang and Mukden to Kirin, the Shan-hai-kwan-Nitt-Chuang portion also serving the purposes of coast defence.

The points requiring to be fortified can only be ascertained on a closer acquaintance with the country affected. The main object would be to fortify mountain passes leading towàds Tongking, Turkestan, Western Siberia and the Russian coast province, the termini of the railways at any of these points being paid special attention to.

\section{5.-Concluding Remakks.}

Summarising the whole question, we find that the following are the most important railways and fortifications required by China :-

1. The fortification of the Capital itself, to protect the Emperor and the Government in Peking; a small railway system and 
fortifications in the Chi-li Province extending from Taku to Petang, and from Liu-cha-shwang to Shan-hai-kwan; Tientsin to be fortified, and forts to be built to the west of Fu-ning-shien, and also in the hills on the routes leading to Mongolia; bridge-heads defending the passages of the Tung-ting-ho; Port Arthur, and perhaps Wei-hai-IVei, to be improved and made into naval stations of the second class only; the main naval base to be made at Kiao-Chou, with a railway to Tsinan-fu to secure the coal supply from Shantung; lastly, to ensure the provisioning of Peking and the Chi-li Province, two railways to the Yang-tse-kiang, to Chin-kiangfu, and to Hankow.

2. For general Imperial defence a line along the coast, from Shanhai-kwan to Canton, with branches to the principal harbours and a central railway from Peking (aic Hankow) to Canton, with four lines radiating towards the Tongking and Russian frontiers.

Fortifications along the coast (beside those in Chi-li and the harbours) for the protection of the mouths of the Yang-tse-kiang and the Canton rivers (the gates of China), Canton, and the most important harbours of the Southern fleet to be specially cared for, and, Iastly, forts to be built on the frontier to defend the mountain passes and protect the railways.

To delay these measures would be dangerous in the extreme.

It is easily understood that China would, more especially as regards her railways, prefer to use her own material, but it would be the greatest folly to wait until the rails could be manufactured; besides which there are a great number of other things which can only be made by skilled workmen and engineers, whilst thousands of well-trained officials would be required to work the lines if they were to be of any real use in time of war.

What would have happened if the viceroys of former years, during the trouble with France, had waited until the Chinese had learnt how to make their own guns, breech-loaders, mines, torpedoes, etc.? Railways are, however, also war material, and those that I have proposed are no less important than other engines of destruction. The latter can be secured from Europe at short notice, whilst railways will take many years to complete on the scale proposed.

Similarly, serviceable fortifications cannot be constructed in a hurry. To fulfil their object in war they must be skilfully planned during peacetime, and China would be well advised to possess models or patterns of these and of railways for future guidance.

By carrying out the most important work, viz., the defence of Peking, China's greatest danger would be overcome, and she might then quietly and steadily complete the other defences and railways required :throughout the Empire.

Let, therefore, the fortification of Peking and the railways thence to the Pei-ho, and from Tientsin to Kaiping and Shan-hai-kwan, be com- 
DEFENCES, MARROURS, AND RAILWAYS REQUIRED BY CHINA. 957

menced at once, the Chi-li coast and Port Arthur defence being at the same time looked to and improsed to the utmost, a main naval base being constructed in the Kiao-Chou Bay. It only requires the assent of the central Government and the Viceroy of Chi-li. Upon their prudence hangs the fate of the Emperor, the Dynasty, and the Empire.

\section{MEMIORANDUAI II.}

\section{Showing the Harhours, Connectixg Railways, etc., Rleuired nY the Nokth CinNa Squadrux.}

\section{1.-INTROduction.}

As Peking, owing to its position, is most liable to attack from the sea, the Northern fleet (or Pejang squadron) is of the greatest importance for the defence of North China.

China has already two naval depôts for the Northern fleet, one at Port Arthur and the other at Wei-hai-Wei, neither of which is however suitable for a large naval base.

\section{2.-Port. Akthur.}

Port Arthur undoubtedly possesses many favourable conditions. Its position at the entrance to the Gulf of Pe-chi-li, is eminently adapted to the defence of the gulf, and the mouth of the Pei-ho; the entrance being narrow (only 400 metres $=328$ yards) is easy to defend, and the harbour is protected from the weather.

There is, however, a comparatively small area of deep water for big vessels, and this is close to the entrance, so that a fleet anchoring here could be seen and would be within range from the open sea. To deepen the bay would be exceedingly difficult and costly, and would take a great deal of time, the bed being extremely hard and firm. Even were the bay of sufficient depth all over, it would not be large enough to hold a numerous fleet. Owing to the narrowness of the entrance (the channel for big vessels is said to be only 35 metres $=40$ yards wide), no fleet could move in and out with ease. In retiring, therefore, before a superior hostile flect, great danger would be incurred and a few ships could render the exit a most difficult matter. Hence this harbour could be rendered practically useless for coast defence, in addition to which during two months of the winter it is ice-bound. This would not be an 'insuperable difficulty if the harbour were intended merely for the defence of the Pe-chi-li Bay and the mouth of the Pei-ho, for since the ice remains longer at the latter place than at Port Arthur, the Chinese fleet could always get away from the latter before an enemy could successfully attack the mouth of the Pei-ho. A smaller number of vessels, intended merely for the protection of the coast in the Pe-chi-li Gulf, might be left at Port Arthur, but the main body of the Northern fleet must be available at any moment to co-operate in the defence of the coast further south, which, owing to the climate, is open to attack all the year round, and more especially so when an attack is rendered impossible on the Pc-chi-li coast owing to the ice. To have the whole of the Northern fleet ice-bound 
in Port Arthur in the winter would be a great mistake, and therefore it is unquestionably not adapted as a main naval base.

In addition to this there are hills all round the harbour, which prevent the erection of arsenals, workshops, etc., and ship-building could never be carried out on a large scale. Just as the natural conditions of the place, which nothing can alter, are opposed to its becoming a harbour of the first class, so it would be equally difficult to fortify or defend the place both from the sea and from land.

The small depots and buildings, etc., at the castern side of the bay are said to be even visible from the sea, and even if this were not so the hills to the south and east could give no protection against a cannonade, more especially at long-ranges; and a bombardment is the more to be feared at this point as a hostile fleet could casily take up a position within range almost in three-fourths of a circle from south to east, whence (more especially from the east) they could enflade the entire length of the bay. To be secure against an attack of this nature, not only must the entrance to this bay be fortified, but the whole coast would have to be protected with numerous batteries, and even so the heaviest guns would not render a bombardment impossible, since the enemy could remain as far from the coast batteries as was safe for their ironclads, and yet keep within range of the interior of the harbour.

Port Arthur is very much exposed to an attack from the land side. The bays on the west and north coasts of the Kwan-tung Peninsula could always be used in calm weather for landing small bodies for an attack on the harbour, whilst 'Talienwan Bay, only two days' march from Port Arthur, would admit of the landing of a whole army.

The English in 1860, before the Peking Expedition, concentrated nearly 100 vessels here, and landed the whole of their forces, and there is therefore little doubt that Port Arthur is in considerable danger from this point if the place possessed sufficient inducement to an attack by land. ${ }^{1}$ It would, therefore, be insufficient to only defend Port Arthur on the coast. The harbour would require to be protected by an impregnable earthwork against an assault, and by detached forts against a bombardment by land batteries or a regular siege.

Lastly, communication from Port Arthur with the rear is a most difficult matter, as a glance at the map will show. Coal can only be brought in by sea, and therefore with safety only in peace-time. All the available approaches by land are most circuitous, and in the event of an attack by sea reinforcements coming by land could not arrive in time. A railway might be built to obviate this difficulty, but it would have to follow the coast so closely that it would never be safe. It is worthy of special note that just north of Talienwan Bay (between Hand's Bay in the north, and Kin-Chou Bay in the south) there is an isthmus, scarcely 18 miles broad, where an enemy, having landed in the bay, could immediately establish himself, cutting off all communication between Port Arthur and

1 It was for this reason that coast batteries at Talienwan were suggested. These appear to have been since constructed (but only by the Japanese after anding) at the end of October, 1894, at Hwa-yuan, to the east of Talienwan. 
DEFENCES, haRBouks, AND RaILWAYS RlQUIRED HY CHINA. 959

the continent, and entirely preventing reinforcements coming to the beleaguered garrison of Port Arthur. ${ }^{1}$

From the above it will be clear that Port Arthur could never serve as anything more than a small harbour and supply depot. As such it is eminently suitable, owing to its position at the entrance to the Pe-chi-li Gulf. It could be sufficiently well fortified without much difficulty, as an enemy would not exhaust his strength on an attack. Whether the existing defences are good enough remains to be seen.

\section{3:- WEI-HAI-WEI.}

This is a fine harbour with plenty of accommodation, but almost entirely exposed to the East and North-East winds, and a large fleet could, therefore, never find shelter from stormy weather. It was on this account that the English Admiral Hope abandoned Wei-hai-Wei Bay as an anchorage in 1860 . There is only one small, bay ("Junk's Anchorage") which appears to give sufficient protection to vessels.

At ebb-tide, moreover, the harbour is only deep enough for vessels of a medium size (up to 6 metres $=19 \frac{3}{4}$ feet), 5 fathoms being only found near the open sea. An enemy could therefore almost entirely overlook the whole of the interior through the wide channels on either side of Liu-kung-tao Island, and every movement of the Chinese fleet could be watched. Nor is there any point on the shore on which a depot, etc., could be built out of sight, the only site available, besides the inner coast of Liu-kung-tao Island, being about 2 kilometres (1 miles) north of the town of Weihai-Wei. This again is so near the western entrance that an enemy could get within easy range from the sea.

These facts would alone suffice to demonstrate the unsuitability of the locality as a main naval base, but in addition to this it could only be fortified with great difficulty to adequately resist an attack both by land and by sea. On the latter side there are two broad entrances, whilst on the land side, only some 4 miles away (as, for instance, at Yung-cheng) small bodies could be easily landed, and at Chi-fu, only a day's march distant, a whole army could be comfurtably disembarked ; ${ }^{\text {indeed, the }}$ French did this in 1860. To reinforce the Wei-hai-Wei garrison would, on account of its position at the very end of the Shantung Peninsula, be a matter of extreme difficulty, and would entail the construction of a long line of rail, more especially with a view to keeping up the coal supply.

Wei-hai-Wei may thus be considered as unsuitable for a main naval base, though it, again, might serve as a small depôt and station, both the entrances being fortified. The defence of the place by land would mean very extensive and costly fortifications round the whole bay.

In any case it would be inadvisable to spend much money on Weihai-IVei unitil Yort Arthur is converted into a naval base of the first class, and for this China has the best place in the world, the Kiao-Chou Bay.

\footnotetext{
${ }^{1}$ It thus follows that the value of Port Arthur is greatly dependent upon Talienwan Bay and the istlmus to the north.

3 The Japanese landed their troops there, some 20,000 men, between the 19 th and 22nd January.
} 


\section{4.-Kino-Chou Bay: (See Pl. 8.)}

The interior of the bay is completely protected from the wind, and so spacious that, notwithstanding the sandy nature of the coast, the largest flect in the world could anchor in more than 5 fathoms of water (30 feet). There is even a larger area of water within the 3 -fathom line which is sufficient for vessels of medium draught, and the anchorage is very good. The bay only freezes partially even in a severe winter, and that never near the entrance, so that vessels would probably never be prevented from going in and out. The narrowest part of the entrance, between Cape Evelyn and Yu-nui-shan, being 3,000 metres wide, a large number of ships can move comfortably alongside one another, and be still further protected by batteries on cither shore. Even in the outer portions of this bay, quite close to the open sea, vessels can lie quite comfortably under cover of Cape Evelyn. The inner bay is completely out of sight of an enemy atsea, owing to the mountains along the coast, and the curve of the coast-line to the north between Yu-nui-shan and Chi-po-san.

The sand on the shores of the inner bay is certainly a disadvantage, but it is probable that the basin could be easily improved by simple dredging, as the sand apparently ali comes from rivers, and the sand thus obtained would be of great value in raising the level of the surrounding land. It would be best to construct this basin, as well as the depôt, arsenals, magazines, docks, etc., on the east side of the bay north of Woman's Island, where the 3 and 5 -fathom lines are nearest the shore. This site is near the entrance, and yet far enough from the sea to be out of danger from a hostile fleet if adequately protected by shore batteries at suitable points.

Woman's Island itself can also be used with advantage for the defence of the harbour. By utilising the dredged sand and blasting the rocks round about, the island can be enlarged, levelled, and connected with the eastern shore by means of a dam. The basin will then be closed to the south, and space obtained for the erection of buildings, etc. The basin should also be closed on the north side by a dam extending from the shore to beyond the 5-fathom limit, enabling the largest ships to reach the harbour comfortably. The harbour could be deepened at will towards the land.

As shown on the plan, a commercial harbour should also be constructed, as soon as thought desirable, to the south of the proposed naval station. For the defence of the outer entrance into the harbour it would suffice at first to construct two batteries ( $a$ and $b$ ) on Cape Erelyn and Yu-nui-shan, with submarine mines between them.

The value and importance of the harbour as a station will determine iater the extent to which it should be further strengthened. Batteries could be constructed at $c, d$, and $e$ to provide more guns to flank the mines, and batteries could also be constructed on the projecting points on the northern shore and on Pile Point $(f, g, h)$, so that an enemy would be under fire before reaching the mines. Torpedo-boats could lie comfortably outside the bar in the bays on the northern shore, protected 
DEFENCES, HARBOUKS, AND RAILWAYS REQUIRED BY CHANA. 961

by the batteries $c, f$, and $g$, and ready to attack the enemy's ships when advancing on the bar. A second fleet of torpedo-boats could also lie inside the bar near Cape Evelyn, in the Tsui-shan Bay, to attack any ressels that had succeeded in penetrating beyond the bar.

Behind this first bay, Bay Rock forms an excellent position for heavy guns in armoured turrets. These would not only command the passage between Cape Evelyn and Yu-nui-shan, but could be directed against the rear and flank of any ships that had entered and attempted to move north into the inner Kino-Chou Bay. The latter could be closed by a second line of submarine mines between the north-eastern corner of Chi-po-san Island and the hills projecting north of Yu-nui-shan, under cover of batteries at $k, l, m$ as shown.

With this object also, the battery $a$ on Yu-nui-shan should be constructed so as to fire in all directions, and turrets would therefore be of special value here. Although the distance between batteries $a$ and $k$ is 500 metres less than that between $l$ and $m$, it would be preferable to lay the submarine mines in the inner entrance between the latter batteries. If both the inner and outer mines were connected with the battery $a$, the enemy would mercly have to silence batteries $a$ and $l$ in order to force the passage through both lines, whereas if the second line of mines is connected with battery $m$, it would still be well protected even if battery $a$ were silenced, being further back and more under cover.

The mines would also be protected between $l$ and $m$ from the interior of the bay, to the east, just where an enemy would endeavour to penetrate and force the entrance into the harbour.

As in the case of Bay Rock, where a battery would defend the mines closing the outer entrance, a battery would be advisable at $n$, on Horseshoe Rock, behind the mines closing the inner passage, the position being a most favourable one for keeping the decp-water channel under fire at close range.

It should be ascertained whether the channel, which is dry at ebbtide, between Chi-po-san and the western continent can be traversed at flood-tide by gun-boats and torpedo-boats. The passage to the west of Chi-po-san would of course be protected by the batteries at $\ell, i$, and $k$, but another dam should, if necessary; be built between Chi-po-san and Crane Point, to prevent the possibility of the second line of mines being circumvented by smaller vessels.

'The defences of the entrance to Kiao-Chou Bay would thus be so strong as to absolutely prevent a hostile flect from penetrating to the inner harbour, and an attempt would certainly therefore be made to destroy the harbour buildings by a bombardment from the sea. For this purpose a position would have to be taken up opposite the coast to the south of Nubble Hill. The points projecting southwards at this place are, however, 6 kilometres ( $3 \frac{a}{ \pm}$ miles) from the basin, and the batteries $f$ and $g$ assisted by that at $h$ (on Pile Point), would still further prevent an approach to the western portion of the land in question by an additional 2 to 3 kilometres (1 $1 \frac{1}{4}$ to $1 \frac{3}{4}$ miles). It would therefore be only necessary, 
as may be seen from the map, to construct 2 more batterics at $o$ and $p$ which would keep hostile vessels more than 4 nautical miles still farther to the east from the position occupied by the docks, arsenal, etc., round the harbour basin.

A bombardment from the sea would thus be useless. Even if the enemy succeded in passing the outer mines, he could not successfully bombard the harbour unless he had penetrated the inner line. The ressels lying behind the latter could, if necessary, withdraw out of range, without even entering the harbour, there being 5 fathoms of water for some 8 to 9 kilometres to the north-west, whilst there are 3 fathoms in the same direction for about 11 kilometres, and to the north for more than 14 kilometres or nearly 8 nautical miles.

The only possible alternative would be, therefore, an attack by land. In the first place an attempt might be made to assault and carry the harbour direct by landing troops further to the east and out of range of the batteries at $p$, as, for instance, in the bay between "Fort Point" and "Middle Point" (Loshan Harbour), or on the east coast of the Peninsula north of the Loshan Hills, if there are suitable points for landing. The harbour-buildings, etc., should therefore be protected by a simple fortification, something like that shown in the plan, but one impossible of assault.

If prevented thus from capturing the place, an enemy might then attempt to take the batteries covering the passage into Kiao-Chou Bay, in the rear, with the object of thus opening the bay for the fleet, and attacking the harbour from the water. The batteries should, therefore, be closed in rear, and, as they are as close as possible to the shore, and therefore low down, they are overlooked and commanded by the surrounding hills. The latter, therefore, must also be fortified, small impregnable forts with light guns being sufficient for the purpose.

'To protect the coast batteries to the east of the entrance against an attack in rear, two such forts should also be constructed at $q$ and $r$ on Nubble Hill and Lung-shan, and two forts at $s$ and $t$ on the heights of Wang-kung-shan, and "Observation Point" on Chi-po-san, for the defence of the battery at $n$ on the opposite side of the passage. These two latter are most important, more especially the one at $s$, as the batteries on Chi-po-san and Cape Evelyn and Pile Point, are isolated and could not be rapidly reinforced from the harbour, whilst their capture would involve the most serious consequences.

If an enemy landed further to the south-west, crossing to Chi-po-san at ebb-tide, and simultaneously advancing across the Wang-king-shan range to the Ti-tung-shan Hills, the batteries $b, d, e, h, k$, and $l$ might fall at one blow, and this would not only render the inner and outer mines powerless from the one side, but the enemy could use the heavy guns in the captured batteries to engage the Bay Rock battery and the batteries $f, c, a$, and $m$, on the opposite shore from $(g)$, including the Horseshoe Rock defences, thus opening the bay for the fleet, and even rendering a bombardment of the harbour itself possible. 
DEFENCES, HARROUKS, AND RAILWAYS REQUIRED BY CHINA. 963

It needs no explanation to show that Observation Point is the only. place for the fort $/$ on Chi-po-san, but the choice of a position for the fort $s$ lics between the Ti-tung-shan and the Wang-king-shan. If placed on the first-named heights, it would certainly prevent the batteries at Cape Evelyn and Pile Point being attacked in the rear; but there is another point to be considered, which I will shortly explain, which argues in favour of its being on the Wang-king-shan, which is, moreover, higher than the Ti-tung-shan. An enemy might land heavy guns and construct batteries for the bombardment of the harbour from the land, and would obtain a greater range than from on board ship, as guns cannot be given so much elevation in the latter case, and heavy guns on land could fire up to 11 kilometres (about $6 \frac{3}{4}$ miles). To meet this contingency, therefore, detached forts should be pushed forward, the natural features of the land around Kiao-Chou Bay being most favourable, and rendering it possible to attain the object with a very limited number of such forts. To the west and north-west, the bay extends so far that no gun could reach the harbour, Crane Point (the nearest point) being 11 kilometres (6 $\frac{3}{4}$ miles) distant.

The construction of batteries for a bombardment on Chi-po-san would be prevented by the proposed fort at $t$; further south, the extreme point of the small peninsula formed by the Siot-su-shan is 11 kilometres further distant from the harbour, but there is so little room for guns, and it is, moreover, under cover of the turrets on Bay Rock, that special forts at $x$ and $y$ would be unnecessary. Further south, only the fort $s$ would be required to secure the Cape Evelyn and Pile Point batteries from being attacked in rear; it should be pushed forward to the Wang-ting-shan so as to keep the enemy beyond the 11-kilometre limit.

To protect the harbour from bombardment, therefore, detached forts would only be required on the east and north sides, and it would probably suffice if the two forts $u$ and $v$ were built on the height marked 1235, N.E. of the Lung-shan, and the height marked 1363, S.W. of Tung-lan-shan respectively. A more careful examination of the intervening ground will show whether any more forts should be constructed, and the same holds good as regards Potato Island to the north, where a fort would perhaps be required at $z$.

In the event of an attack by land, or a siege, the harbour in KiaoChou Bay could be easily and rapidly reinforced, owing to the fact that, unlike Port Arthur or Wei-hai-Wei, it does not lie at the extreme end of a peninsula but close to the heart of the country, and troops could be casily brought up from the Yang-tse-Kiang or the Pei-ho if it was found they were not required there, and that the enemy intended a blow at the main naval base, and the destruction of the fleet. Kiao-Chou is, of course, not so close to the Pe-chi-li Gulf as Wei-hai-Wei or Port Arthur; but then, on the other hand, no hostile fleet would attempt to enter this gulf with the main Chinese squadron ready for action in their rear at Kiao-Chou. They would, moreover, in order to attack the Pei-ho, have to have a second fleet strong enough to hold the Chinese fleet at KiaoChou in check. 
For a direct defence of the Pe-chi-li Gulf, it would be sufficient to maintain adequate supplies in neighbouring depôts for the Chinese squadron in these waters. In the event of bad weather, or if attacked by an overwhelming force, they could seck shelter in some fortified harbour, such as Port Arthur or Wei-hai-Wei.

One great advantage of making Kiao-Chou the main naval base lies in the fact that the fleet can be easily supplied with good coal from the interior, and this is impossible at Port Arthur or Wei-hai-Wei. A short line of rail would suffice to the coal mines at Wei-shien, with an extension to Tsi-nan-fu, ${ }^{1}$ the mines at Lin-chi-shien (Lintz), Po-shan-shien and Chang-kiu-shien being thus also opened up. A second line to $\mathrm{Yi}$ Chou-fu and to Tsi-nan-fu on the main Peking-Chin-Kiang-fu railway would also open up the coal district in these parts.

The Kiao-Chou Bay is connected with the Pe-chi-li Gulf by means of the Kiau-ho Kiau-Lei-Nan-ho and Kiau-Lei-Pei-ho rivers. These waterways could probably be improved at a small cost, and might be utilised by even gun and torpedo-boats, which would then be enabled to enter the mouth of the Pei-ho by the shortest possible route, and proceed direct across the Shantung Peninsula. The importance of this in time of war can scarcely be over-estimated, whilst it would also be a most useful route in peace-time for the coasting trade from Southern China to Pei-ho.

Lastly, it should be noted that the establishment of a base at Kiao"Chou would be of the greatest service not only to the fleet but to an army. $\mathrm{By}$ fortifying the harbour the place would be converted into an entrenched camp, which would be of the greatest value in a defence of the country.

No portion of the Chinese Empire, with the exception of some of the provinces bordering on Russia, can be so easily acquired by an enemy as the Shantung Peninsula. With Kiao-Chou undefended, nothing would be easier than to land an army there and take up a defensive position straight across the peninsula to the Pe-chi-li Gulf, in rear of the waterway referred to above, and thus sever it from the interior. Its recapture would be most difficult, whilst the enemy could make use of it to prepare for a further advance, as was done at Chi-fu in 1860 .

If, on the other hand, Kiao-Chou Bay is well fortified in connection with the harbour, not only is the most exposed position of the Shantung Peninsula protected, but an enemy could be easily expelled by an army supported by this fortress. No invasion of the country could ever be attempted without the capture of Kiao-Chou.

\section{Conclusion.}

As stated in the Introduction, these Memoranda were written more than ten years ago, the portion relating to Kiao-Chou as far back as November, 1883.

They were, moreover, written in the interests of China, because at that time the development of the country under the agis of $\mathrm{Li} \mathrm{Hung}$

\footnotetext{
${ }^{1}$ Now to be built by Germany.
} 
DEFENCES, HARBOURS, AND RAILWAYS REQUIRED HY CHINA. 965

Chang gave reason to hope that China might become a valuable ally of Germany.

I need now no longer hesitate to submit them to the public, since the possession of Kiao-Chou Bay (having been effected by treaty) is not thereby compromised.

The papers are only interesting from a theoretical point of view, everything I have proposed or written resting purely on theory, never having visited the localities under discussion. The events of the last decade, more especially the Japanese war, and the fact that the railways constructed or under consideration are the very ones which $I$ mentioned as important, go far to justify the correctness of my vicws, although it would of course be now obviously wrong to suppose that I hold to everything contained in the above memoranda, written solely in the interests of China herself. Circumstances have most materially altered in many respects. I will therefore merely add a few observations on the cession of Kiao-Chou Bay to Germany.

In the first place, it will give a considerable impetus to the railway question. Whereas, formerly, the railway connection between Peking and the Yang-tse-kiang and Canton, besides the Chi-li lines, were of first importance, the proposed lines from Kiao-Chou are now of greater value, with a view to opening up the coal districts of Tsinan-fu and Yi-Chou-fu, not only for the German fleet but for traffic in Far Eastern waters generally.

Secondly, Kiao-Chou Bay, as the gate of European industry, implies the further opening up of the country to the west, across the. Huang-ho to the proposed great central railway from Peking, through Hankow, to Canton. To this end a line should be constructed from Tsi-nan-fu through Tung-chang-fu and Taming-fu to Changte-fu, which I proposed in 1884 (see Pl. $\bar{\imath}$ ), but which.I referred to, in No. 1 Memorandum, as being of minor importance.

The line should be continued westwards from Wei-huei-fu through Honan-fu to Siar-fu, and eventually perhaps might even run to LanChao-fu and Sin-Chao-fu, through Hami, Semipalatinsk and Tomsk, forming a future European Chinese Berlin-Kiao-Chou Express Service.

The possession of the Bay itself is important in a different sense from what it was formerly. The proposed commercial harbour would eventually extend considerably to the south, or else be transferred to the northern side of the main harbour. But to make this a main naval base for - Germany (on the lines proposed for China) cannot be thought of ; and whilst it would have been necessary in the case of China to convert the place into a fortified position, there is no necessity for us to do so. 'The safety of the German Emporium must be primarily attained by closer relationship with China, who should on their part count it as fortunate that such an important position has fallen to a friendly Power. At the same time it must not be forgotten that owing to the inability of the Central Government to maintain their authority in the provinces, disturbances not unseldom occur which are fraught with danger to foreign colonies. To ensure the steady development of German trade, etc., it roL. XLII. 
behoves us to practically guard against such dangers when the friendly attitude of the Chinese Government and our own peaceful intention will avail us nothing.

To ensure the peaceful development of harbour and station, it will however suffice to construct defensive works round the buildings with a view to prevent any sudden incursion by hordes of armed marauders, and with the aid of modern weapons this work may be of a fairly simple nature, mostly earthwork, for which labour can be obtained very cheaply. Anything further must depend upon the growth of the place and future developments.

Permanent fortifications are only required to protect the entrance to the bay, with a view to preventing a possible attack from the sea, and I stated in November last what measures I thought necessary in this connection,' viz.:-Batteries at Cape Evelyn, Yu-nui-shan, and on the north-eastern corner of Chi-po-san with intervening lines of mines, and armoured turrets on Bay Rock.

I am, of course, unacquainted with the intention of the Imperial Government. Considering, however, that even at Kiel the defences are confined to the mouth of the bay, they will scarcely fail to take the necessary measures for fortifying the entrance to Kiao-Chou Bay.

Although, perhaps, my proposals for the defence of China are now of no value, and may never attain to any importance, I trust that general interest in the matter inay justify their publication.

The paper, as well as the accompanying maps, have been carefully corrected with L. Bretschneider's map of China, 1896 (the one consulted), which it is as well to have by in a study of the paper.

The following notes from the above map are also useful :-

Capital of a province or prefecture shown by

the termination

Independent sub-prefecture

Department

District

Shan

Ling -

"Kiang," "Ho," “Shui," " Ki,"

$\mathrm{H}$

Chang

Chen

Pei

Nan

Tung -
- "fu."

- "ting."

- "chou."

- "nien."

- Mountain.

$\int$ Mountain pass or $\{$ ridge.

- River.

- Lake.

- Town.

- Mart.

- North.

- South.

- East.

- West. 
